\title{
ECONOMIC FEASIBILITY OF CLONAL OIL PALM PLANTING MATERIAL
}

\author{
NUR NADIA KAMIL*; MEILINA ONG-ABDULLAH*; AHMAD TARMIZI HASHIM*; ZAMZURI ISHAK*; \\ BALU NAMBIAPPAN* and AZMAN ISMAIL*
}

\begin{abstract}
Tissue culture-derived planting materials have been proven to outperform the standard dura $x$ pisifera $(D x P)$ materials, in which most clones have reportedly surpassed the standard DxP performance by at least $20 \%$ on average in terms of fresh fruit bunch (FFB) yield on a per hectare basis. This advantage seems to benefit the industry players as higher productivity will lead to higher income. However, the cost of producing clonal materials is considered as one of the major bottle-necks in the large scale usage of clonal planting materials in the oil palm industry. This article aims to evaluate the economic feasibility of clonal oil palm planting materials using a cost-benefit analysis. Among the financial parameters used to measure the feasibility are namely the net present value (NPV), internal rate of return (IRR) and payback period. Based on these parameters, the study suggests that the clonal planting material is a viable venture and worth the investment as it provides better yield, both in terms of FFB and oil yield, which translates into better returns for the industry players despite the premium price of clonal materials as compared to that of the seed-derived standard DxP.
\end{abstract}

Keywords: clonal planting material, DxP seeds, FFB yield, tissue culture, cost-benefit analysis.

Date received: 2 May 2019; Sent for revision: 23 May 2019; Accepted: 29 September 2019; Available online: 29 July 2020.

\section{INTRODUCTION}

\section{Background}

Demand for palm oil has been growing steadily since the past decades. This sterling growth in demand is supported by the increasing number of the world's population. The world's population in 2015 was around 7.3 billion and it is expected to reach 8.5 billion by 2030 (UNCTAD, 2016), which translates into $16.4 \%$ growth in 13 years. Against this backdrop, demand for palm oil and other oils and fats is expected to grow at a similar rate to feed the growing population. However, the production of palm oil is subject to the availability of suitable planted area. Arising from limited arable land, the growth of palm oil production in Malaysia is decelerating (MPOB, 2018a). One of the ideas to increase palm oil production within the limited area

\footnotetext{
Malaysian Palm Oil Board,

6 Persiaran Institusi, Bandar Baru Bangi,

43000 Kajang, Selangor, Malaysia.

E-mail: nadiakamil@mpob.gov.my
}

is to produce planting materials with higher yields such as clonal oil palms.

For a perennial crop like oil palm, the reliability and value of the planting material is a major concern to the planters. Various factors, not limited only to yield components, such as resistance to diseases, drought, altitude and low temperatures need to be taken into consideration in choosing the best material. Oil palm first came into Malaya (now known as Malaysia) by seeds and were planted in Tennamaran Estate, Selangor, in 1917. As the demand for palm oil products increased, oil palm productivity needs to be improved. Prior to 1960, the Department of Agriculture of Malaysia together with the private plantation companies had introduced the basic oil palm breeding materials from Indonesia and Africa (Rajanaidu et al., 2013). Since then, several germplasm exchange programmes were initiated with the objective of boosting the yield by leveraging genetic diversity as oil palm being nonindigenous to Malaysia was initiated from a narrow genetic base. Genetic improvement of oil palm through conventional means was found to be costly 
as the cycle can take up to 10 years (Low et al., 2008) and even longer at approximately 19 years per cycle if phenotypic selection is carried out (Kushairi et al., 2018). This drawback instigated breeders to resort to alternative methods to expedite introduction of new planting materials. Vegetative propagation of oil palm via tissue culture was deemed as a potential technology to fast track production of elite palms. Vegetative propagation which employs the tissue culture technique is essentially a plant regeneration process whereby cuttings from a parent plant is grown on synthetic media to produce more plants or known as clones. Malaysia reported her first clonal oil palm in 1980/1981, inspired by the success of Rabechault and Martin in regenerating oil palm plantlets or also known as ramets from callus cultures derived from leaf explants in 1976 (ISOPB, 1985). Oil palm tissue culture is primarily initiated from the callus induction of its young leaves. The callus forms along the cut edges where the veins are exposed and would eventually lead to somatic embryo formation and maturation, shoot regeneration, rooting and finally the regeneration of new viable ramets (Low et al., 2008). Generally, the oil palm tissue culture process takes about 5-6 years from start of culture up to the production of marketready ramets (Sundram et al., 2010).

\section{Performance of Oil Palm Clonal Planting Material}

Clonal oil palm is known to offer higher yield. In the early years of clonal oil palm, the oil yield from the planting material was anticipated to increase by at least 30\% (ISOPB, 1985). Besides the improvement in oil yield, the clonal palm is also capable of improving the FFB yield. Given favourable soil and rainfall conditions and coupled with good management practices, the FFB yield and oil yield of the clonal oil palm is $40 \%$ and $50 \%$ higher, respectively, as compared to the yield of standard DxP materials (Khaw and Ng, 1997). Federal Land Development Authority (Felda) trial plots of clones also provide a positive outcome where their clones are capable of producing more than $8 \mathrm{t}$ of oil ha- $\mathrm{yr}^{-1}$ (Alwee $e t$ al., 2010). This is translated into an increase of more than $50 \%$ as compared to the Malaysian palm oil yield average of $3.69 \mathrm{t}$ in 2010. Given the same age of the oil palms and the same area of planting, the clonal palm could yield FFB of up to $32.60 \mathrm{t} \mathrm{ha}^{-1} \mathrm{yr}^{-1}$, which is an increment of $24.96 \%$ over the yield of the standard DxP materials of around $26.09 \mathrm{tha}^{-1} \mathrm{yr}^{-1}$ (Kushairi et al., 2010).

Due to its superior yield performance over the standard DxP seedling materials, the clonal oil palm has been receiving increasing interest among the big plantation players in Malaysia. Felda, Sime Darby Plantation Berhad, Applied Agricultural Resources Sdn Bhd (AAR) and IOI Plantation Sdn Bhd are among the pioneers of tissue culture programme in
Malaysia. They established their own tissue culture laboratories mainly to supplement their own estates. As of 2015, the production of clonal oil palm planting materials in Malaysia was estimated to be around 6.77 million ramets (Alwee, 2018). Assuming the production of ramet grows by $10 \%$ every year, by 2017 it is expected to be around 8.19 million. The expansion of ramet production is limited as it depends on the availability of ortet. A large number of ortets would be required to increase the production; for example, to produce 500000 ramets, 100 ortets are required (Soh et al., 2017). Usage of high yielding ortets from superior progenies will increase the efficiency of cloning (Alwee et al., 2010). However, the selection of 'true' high yielding palms as ortets have always been difficult. In choosing good ortets, it is more efficient to use oil-to-bunch as compared to FFB yield (Soh, 2010). Besides the issue of availability of 'good' ortets, planting of clonal oil palm also exposes planters to the risk of mantled fruit or known as abnormality. However, when suitable cloning protocols are used, the incidence of abnormalities (mantled fruitlets) is small whilst other defective traits that occur in standard DxP tenera palms are eliminated (Mutert and Fairhurst, 1999).

With the expectation of better returns resulting from the improvement on FFB and oil yields, this would successively lure more plantation companies to invest in setting up tissue culture laboratories, and those with existing facilities to expand to cater for the increasing demand for clonal oil palms. Despite its promising yield, the usage of clonal material is restrained by the concern of mantled fruits which would jeopardise yields and ultimately affect revenues of plantation companies. However, through leveraging on the advancement in micro propagation as well as experience, tissue culturists have been successful in capping abnormality rates to less than 5\% (Tarmizi et al., 2018). Regardless of the fact that the tissue culture process has very much improved with further quality checks in place, oil palm clones continue to be discriminated with only $2 \%$ clones being used as commercial planting materials (Ong-Abdullah et al., 2006). The poor uptake of clones could also be attributed to the less than competitive pricing compared to seed-derived DxP.

\section{Cost-benefit Analysis (CBA) of Clonal Planting Material}

Studies conducted independently by agencies involved in oil palm cloning reported stark improvement in yields from estates that included clonal materials in their planting. From the economic perspective of oil palm planters, this leap in yield will certainly translate into higher revenue collection. However, the increment in revenue is deemed insufficient to ensure the long-term 
profitability of adopting clonal planting materials. In order to verify the situation, a feasibility assessment of the technology through CBA was recommended. The application of CBA by Janssen et al. (2018), in the study of breeding programme provided guidelines to the private companies in determining the optimal number of inputs that maximise the net present value (NPV) of the programme. Similar methodology was used in assessing the costs and benefits of indigenous soil and water conservation (SWC) measures in Sikkim Himalaya. Based on the parameters such as NPV, internal rate of return (IRR), payback period, and sensitivity analysis, the finding of the SWC study suggested that it was worth to implement the SWC practices (Mishra and Rai, 2014).

With the current interest on clonal planting, it would be timely to evaluate the cost and benefits of utilising clonal planting materials as opposed to only using the standard DxP seedlings. On initial comparison of the profitability of planting clonal palms vs. seed-derived DxP hybrids, it was revealed that despite having to purchase these elite planting materials at higher price, the benefit gained from profit outweighs the cost (Ooi, 2005). Nonetheless, aside from its excellent performance on both FFB and oil yield, the investment in the production of clonal planting material is costly to plantation players. Amongst other costs to be considered are the capital expenditure on building, room for media preparation, washing and sterilisation, culture transfer, etc. However, again the study shows that the venture into clonal material production is still financially viable, provided that the plantlets are sold at a price of at least RM 20 each. If it were sold at RM 15, the investor would need to produce 700000 plantlets annually on double shift basis to offset the lower price offered (Zamzuri et al., 1998).

\section{METHODOLOGY}

In assessing the financial feasibility of the clonal oil palm investment, a CBA focusing on the NPV was performed, which involved evaluating the total cost incurred in the cultivation of oil palm using the clonal planting materials. The estimated cash flows were based on the current estimated production cost and anticipated productivity. The result of the NPV analysis was then used to compare the economic benefit of clonal materials against the standard DxP seedlings.

The analysis was done from two different perspectives: (1) from the viewpoint of nonintegrated players, and (2) from the viewpoint of integrated players. Non-integrated players are defined as entrepreneurs who earn revenue from the sales of FFB to the mills only, while integrated players are defined as entrepreneurs who also earn revenue from the sales of crude palm oil (CPO). The differentiation was made as there is a variation in terms of operating cost between these two groups of entrepreneurs. Due to the economies of scale, the integrated players are assumed to operate at a lower cost compared to the non-integrated players.

\section{CBA Framework and Assumptions}

The assumptions made in this study are elaborated as follows. The growth of clonal oil palms was assumed to be similar to that of standard DxP oil palms. In theory, oil palm has the potential to produce FFB over a life-span of 30 years or so. However, in normal practice, due to the height issue, planters usually keep the oil palms until the age of 25 years before considering replanting. Oil palm starts to bear fruits about 30 months after field planting. Therefore, in this study revenue is considered as early as two years after planting (Zulkifli et al., 2010). The FFB yield then increases year-by-year until it reaches its peak at the age of 9-18 years and gradually declines thereafter (USDA, 2012).

Figure 1 shows the average FFB yield of estate sector in Malaysia according to the oil palm age profile (MPOB, 2018b). This study used the period of analysis of 25 years based on the standard practice of the Malaysian oil palm planters.

\section{Discount Rate of the Cash Flow}

A discount rate of $7.4 \%$ derived from the Capital Asset Pricing Model (CAPM) was applied to the cash flows. Among the assumption used in the CAPM were the risk-free rate of $3.9 \%$ on 10 year Malaysia Government Security (MGS), average Kuala Lumpur Composite Index (KLCI) market return on $9.8 \%$ and beta of 0.6 . The beta is the average beta of three plantation companies on KLCI, i.e. Sime Darby Plantation Berhad, Genting Plantations Berhad and TH Plantation Berhad (Bloomberg, 2017). This discount rate incorporated the market risk that is unpredictable and impossible to avoid. In addition, the discount rate considered the level of risk of plantation companies toward changes in the market, proxied by the above beta.

\section{The Initial Outlay}

The initial outlay is the amount required to start a business or a project. For oil palm plantation, the initial outlay is assumed to be the development cost of the estate. This cost is also known as the establishment cost, which is non-recurring. It involves activities such as land clearing, road construction, drain construction, holing and planting, terracing and few others. This cost category also includes the cost of purchasing planting materials. 


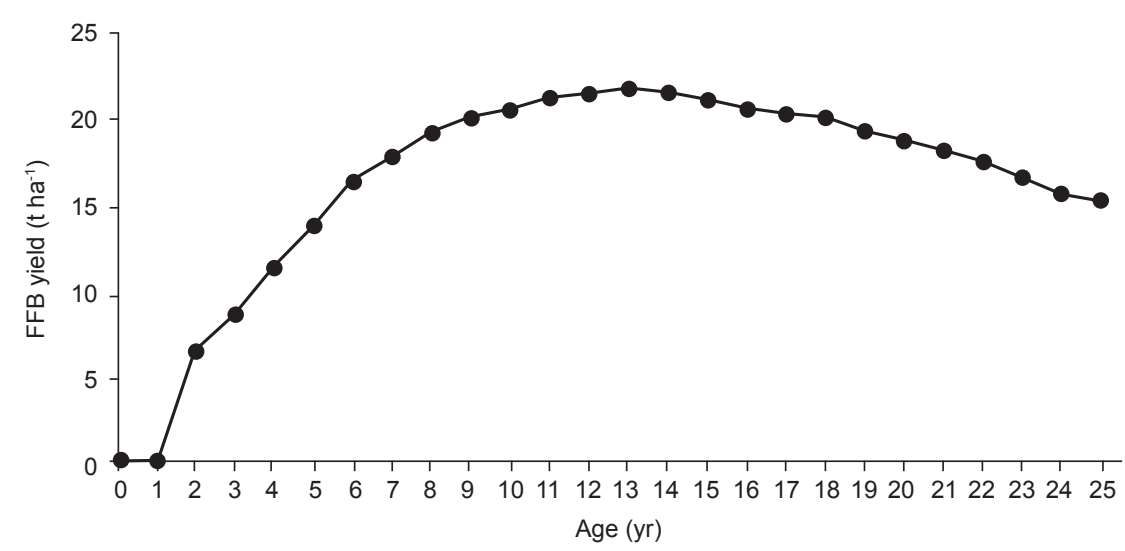

Source: MPOB (2018b).

Figure 1. The average of fresh fruit bunch (FFB) yield according to oil palm age profile.

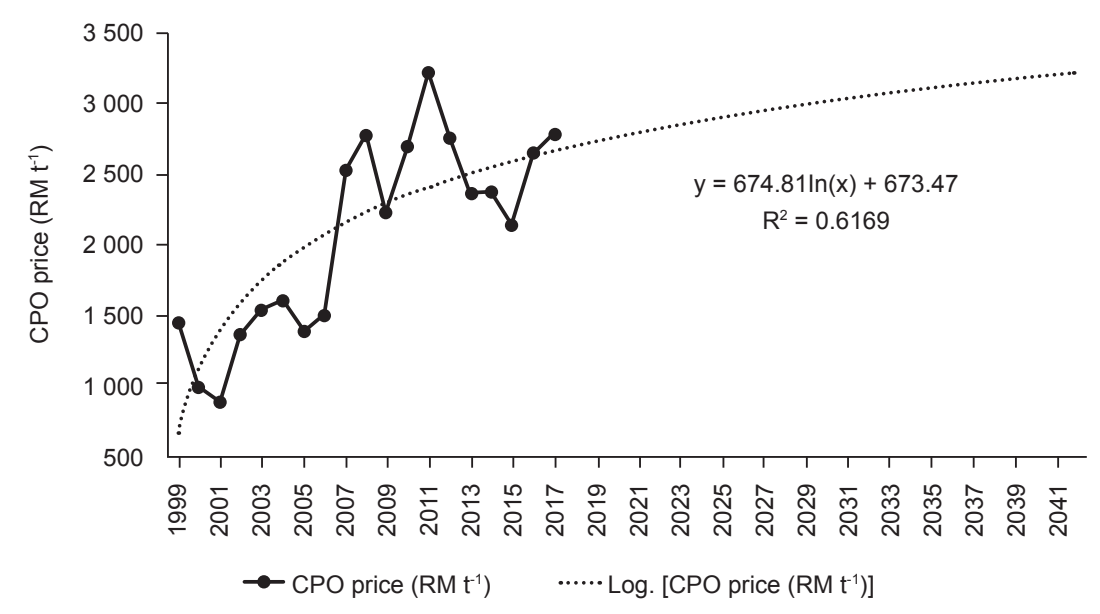

Figure 2. Derivation of crude palm oil (CPO) prices.

\section{Operating Expenses (OPEX)}

The operational cost of oil palm cultivation is divided into two categories, namely, the immature cost and mature cost. Since the oil palm starts yielding at the age of 30 months, the operating costs involved before this period (immature cost) are mainly the maintenance costs. These include the upkeep cost which encompasses activities such as weed control, fertiliser application, pests and diseases control. The major cost items under upkeep activities is fertilisation. To obtain good yields, optimum application fertiliser is recommended during the early development as it relates to the rate of frond production which in turn affects the numbers of fruit bunches produced (Henson and Dolmat, 2004).

At the maturity stage (above 30 months), the operational costs involved are the upkeep cost, harvesting cost as well as transportation cost. This study assumed that there is no difference in the agricultural practices between clonal planting materials and standard DxP materials, particularly on fertiliser application. Hence, the operational costs for these two items are the same, as the nutrient demand of clones does not differ much from that of standard DxP (Alwee et al., 2010). The study assumed the operational costs grow at $2 \%$ annually according to the average inflation rate of Malaysia from 20002016 (The World Bank, 2017).

\section{CPO and FFB Prices}

For the calculation of revenue, the $\mathrm{CPO}$ prices were derived from a univariate projection as in Figure 2. The projection was made based on historical trend of annual average CPO prices from 1999 to 2017. Meanwhile, the FFB prices were computed as $20 \%$ of the CPO prices. The determination of FFB price is largely dependent on the oil extraction rate (OER); hence, this study used $20 \%$ to reflect the 10 year average of national OER.

\section{FFB Yield and OER}

Data on FFB yield and the OER were provided by the Advanced Biotechnology and Breeding Centre of the Malaysian Palm Oil Board (MPOB), based on the internal report of clonal material 


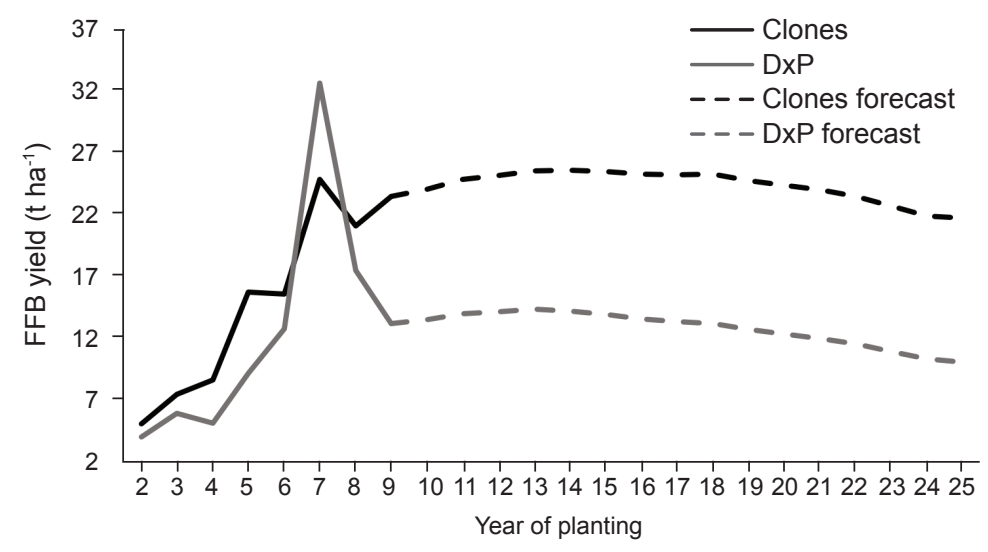

Figure 3. Fresh fruit bunch (FFB) yield of clonal vs. dura $x$ pisifera (DxP) of Estate A.

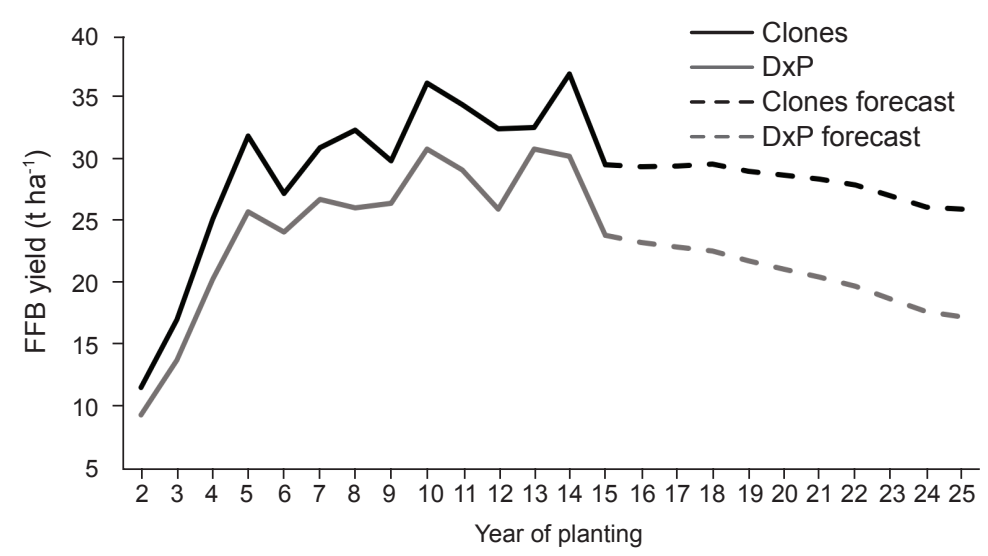

Figure 4. Fresh fruit bunch (FFB) yield of clonal vs. dura $x$ pisifera (DxP) of Estate B.

performances in different places in Malaysia. This study used two sets of data, in which one was from the MPOB Research Station and the other from a private plantation company, which will be known as Estate A and Estate B, respectively. Estate A is located in Peninsular Malaysia and Estate B is located in East Malaysia. The yield pattern of these two estates were tabulated in Figures 3 and 4. As the clonal oil palm is expected to be superior than the DxP in terms of the oil yield, the assumed OER for the clones and DxP was $25 \%$ and $20 \%$, respectively. The projection of the FFB yield in Estate A and Estate B over the 25 years of planting was made based on the general yield trend of oil palm in Malaysia.

The cash flow analysis was based on the above assumptions, and the key parameters, namely, the NPV, IRR and the payback period were calculated to examine economic benefit derived from the differences in the planting material used.

\section{RESULTS AND DISCUSSION}

Table 1 shows that the calculated NPV of clonal planting material outweighs the NPV of DxP seedlings in both estates. Regardless of the tagged price for clones, their NPV is still higher than that of DxP seedlings. Higher NPV implies that the company is paying less than the clonal planting material worth. The usage of NPV in the investment decisionmaking process takes into account the relationship between the present and the future values of money. Investors invest money only with the intention of reaping the rewards in the future. Hence, the NPV is the tool to calculate whether the stream future cash flows is worth more than the present value of money needed to invest. In addition, the NPV nets out the cost of acquiring future cash flows. Therefore, a positive NPV indicates that the investment is worth proceeding.

The benefit of clones also can be seen from the calculated IRR. The IRR is a complementary indicator for investment decision-making. The IRR for a stream of cash flows is the rate at which the NPV of investment is break-even (equal to zero). Typically, the IRR is compared to a discount rate of the cash flows, which reflects the cost of capital. The basic rule is the IRR should be equal to or larger than the discount rate, and the attractiveness of this rate depends on the magnitude difference between the IRR and the discount rate. Given the discount rate of $7.4 \%$ as mentioned in the preceding section, the 
IRR for the investment in clonal planting materials is greater than that of the investment in standard DxP seedlings. For example, if Estate A were to purchase its clonal planting materials at the price of RM 15/plantlet, the return for each dollar invested in clonal planting material will be $33 \%$. However, if Estate A were to purchase the plantlet at the price of RM 40/plantlet, IRR from the investment would obviously be lower, at $28 \%$, yet still higher than the return from investing in DxP seedlings. With regards to the payback period, aside from boosting revenue, the superior yields obtained from clonal oil palm would expedite the recovery process of the investment cost incurred. The financial analysis carried out indicates that it is feasible for estates to invest in planting clones as they provide a better return regardless of the location of the estates. This finding is consistent with the results of economic analysis by Maheran and Chan (as cited in Nair, 2010) which stated that the higher productivity of clonal materials not only suffice to pay-off the high initial investment but also provides a better return compared to that of the conventional planting materials.

On contrary, the financial analysis in Table 2 seems to work against the non-integrated players, which were found to be better off by investing in DxP seedlings. The usage of clonal planting material reduces the present value of their investment and gives them lower return as compared to growing DxP seedlings. This group of entrepreneurs generally operates on a small scale, hence, are unable to reap the benefits of economies of scale. Based on the cost of production survey done by MPOB, the cost of production for a private limited company is $10 \%$ higher than the cost of production of public limited company. Due to this disadvantage, the substantial increase in the FFB and oil yield offered by the clonal planting materials is insufficient to offset the increase in the investment cost arising from the purchase of clonal planting materials. A similar situation was reported by the Indonesian rubber industry, in which only small percentage of the smallholders had access to highly productive rubber clonal material in 1996 due to capital and information constraint (Penot and Ruf, 2001).

Nonetheless, the non-integrated players can enjoy the benefit of high yielding material if they were given at least $5 \%$ premium on the FFB price sold to the mill. Due to the financial constraint, the non-integrated players will choose to use the clonal materials when the financial benefits outweigh the cost. Hence, a premium to the standard selling price of FFB is needed to motivate the non-integrated players to plant clones in their estates. Similar situation also applies in the case of sustainability certification. In a review of certification by Kuit and Waarts (as cited in Hutabarat et al., 2018), they found that farmers are often focused on price premiums whereas the main benefits are to be gained from the increase in production and better market access.

Table 3 shows that the non-integrated players obtain higher NPV by planting their oil palm trees using the clonal materials. The financial analysis of having premium on FFB prices shows a conflict between the NPV and IRR. An investment in clonal material at RM 40/plantlet in Estate A yields a higher NPV of RM 2068 compared to RM 2062 from a DxP seedlings in the same estates, but the IRR of the same DxP seedlings investment is higher than the IRR of the clonal materials at RM 40 / plantlet.

TABLE 1. COMPARISON OF INVESTMENT IN Dura $x$ Pisifera (DxP) AND CLONAL PLANTING MATERIAL OF INTEGRATED PLAYER

\begin{tabular}{lccccccccc}
\hline & \multicolumn{3}{c}{ Estate A } & & \multicolumn{3}{c}{ Estate B } \\
\cline { 2 - 4 } \cline { 8 - 10 } & DxP & \multicolumn{2}{c}{ Clones } & & DxP & \multicolumn{2}{c}{ Clones } \\
\hline Cost per planting material (RM) & 10 & 15 & 40 & & 10 & & 15 & 40 \\
Net present value (RM ‘000) & 2320 & 5193 & 4915 & & 5109 & 8078 & 7801 \\
Internal rate of return (\%) & 25 & 33 & 28 & & 40 & 51 & 43 \\
Payback period (yr) & 5.8 & 4.5 & 5.0 & & 3.5 & 3.0 & 3.3 \\
\hline
\end{tabular}

TABLE 2. COMPARISON OF INVESTMENT IN Dura $x$ Pisifera (DxP) AND CLONAL PLANTING MATERIAL OF NON-INTEGRATED PLAYERS

\begin{tabular}{|c|c|c|c|c|c|c|}
\hline \multirow[b]{3}{*}{ Cost per planting material (RM) } & \multicolumn{3}{|c|}{ Estate A } & \multicolumn{3}{|c|}{ Estate B } \\
\hline & \multirow{2}{*}{$\begin{array}{c}\mathbf{D x P} \\
10\end{array}$} & \multicolumn{2}{|c|}{ Clones } & \multirow{2}{*}{$\frac{\mathbf{D x P}}{10}$} & \multicolumn{2}{|c|}{ Clones } \\
\hline & & 15 & 40 & & 15 & 40 \\
\hline Net present value (RM ‘000) & 2062 & 2034 & 1912 & 3834 & 3806 & 3684 \\
\hline Internal rate of return $(\%)$ & 33 & 31 & 27 & 49 & 47 & 40 \\
\hline Payback period (yr) & 5.3 & 5.4 & 5.9 & 3.3 & 3.4 & 3.8 \\
\hline
\end{tabular}


TABLE 3. COMPARISON OF INVESTMENT IN Dura $x$ Pisifera (DxP) AND CLONAL PLANTING MATERIAL OF NON-INTEGRATED PLAYERS GIVEN THE 5\% PREMIUM ON FRESH FRUIT BUNCH (FFB) PRICES

\begin{tabular}{lcccccccc}
\hline & \multicolumn{3}{c}{ Estate A } & & \multicolumn{3}{c}{ Estate B } \\
\cline { 2 - 4 } \cline { 6 - 8 } & DxP & \multicolumn{2}{c}{ Clones } & & DxP & \multicolumn{2}{c}{ Clones } \\
\hline Cost per planting material (RM) & 10 & 15 & 40 & & 10 & 15 & 40 \\
Net present value (RM ‘000) & 2062 & 2190 & 2068 & & 3834 & 4094 & 3971 \\
Internal rate of return (\%) & 33 & 33 & 28 & & 49 & 49 & 42 \\
Payback period (yr) & 5.3 & 5.2 & 5.7 & & 3.4 & 3.3 & 3.7 \\
\hline
\end{tabular}

A similar conflict was noted for Estate B. In these cases, concentrating on the NPV calculation is the best option because the NPV measures the choice of investments in terms of the net ringgit. Thus, it will be easier for the investor to allocate their capital. Meanwhile, the IRR calculation is influenced by the timing of cash flows, in which an investment that recovered sooner (has a shorter payback period) will generate higher IRR. Thus, for the case of nonintegrated players with FFB price premium, the investment in clonal planting materials is preferred over the standard DxP seedlings.

\section{CONCLUSION AND RECOMMENDATION}

The usage of oil palm clonal planting materials has yet to make a significant impact to the industry, as evidenced by the total production number of ramets in 2015, where it only accounted for less than $10 \%$ of the total oil palm seed production for that year. Despite the unfavourable uptake by the industry, the advantage of clonal planting materials should not be denied. The inefficiency of the tissue culture process and the risk of fruit mantling as well as other somaclonal variation are amongst the main challenges in advocating the use of oil palm clonal material at a larger scale (Ong-Abdullah et al., 2018). However, through continuous research and development the tissue culture process has improved in terms of efficiency and in conformity. Coupled with the discovery of KARMA and its potential to be developed into a marker for early screening of mantling in clones at the nursery stage (OngAbdullah et al., 2015), this progress over the years is expected to instil greater confidence in utilising clonal material for commercial planting among the industry players (Soh, 2018). A part from these issues, the study believes that the poor reception of clonal oil palms as commercial planting is also partly due to the lack of awareness of the potential returns that can be yielded from the clonal material on a longer term. The higher initial investment arising from the higher cost of clonal seedlings compared to that of standard DxP seedlings is one of the reasons that the industry players, particularly the small plantation players, are hesitant to use them. The selling price of clonal material was 50\% higher than that of standard DxP seedlings (Wahid and Simeh, 2009). Provided that there are no economic shocks and the market is able to give returns of more than $9 \%$, the study believes that the investment in the clonal material is beneficial to the plantation companies in Malaysia. This argument would holds true with the assumption that the $\mathrm{CPO}$ is traded above an average of RM $2500 \mathrm{t}^{-1} \mathrm{yr}^{-1}$ for the next 25 years. The investment of clonal planting materials, particularly in a very favourable environment such as good weather condition, fertile soils and good agriculture and management practices help to further boost the FFB and oil yields and reduce the period of capital expenditure recovery. In this study, the usage of clonal planting materials produces a positive NPV as early as 4.5 years after planting for the integrated player and is highly profitable thereafter. However, the study found that the investment in clonal materials is unattractive for the non-integrated players that depends solely on the sale of FFB to the mills unless they are able to obtain support from the government on the FFB prices. Being a perennial crop that lasts more than 25 years, the investment in oil palm needs to be scrutinised. Once the oil palm has been planted, it is inadvisable to chop it down during that 25 years of the palm's lifetime because it is uneconomical to do so except in the event of an outbreak.

In realising the aims of having better national FFB and oil yield performances, the usage of clonal material needs to be intensified. As the study suggested that non-integrated players are financially incapable of adopting clones despite its outstanding performance against the standard DxP seedlings, it is recommended that the government to assist them by offering a special scheme to the small plantation players, i.e. by allowing them to sell the FFB at premium price with the expectation of better fruit grades and higher OER. This special scheme is similar to contract farming, which involves appointing a company as a contractual partner to purchase FFB from the non-integrated players at a premium price on the basis of an expected $2 \%$ $3 \%$ gain in OER of clones as compared to standard DxP. The clones will be planted within the area of participating companies to ensure that the fruits will 
be delivered to the mills registered under the scheme (Ong-Abdullah et al., 2018). This kind of government intervention is found effective in increasing the production of agricultural products. Denning et al. (2009) found that subsidising the inputs for the smallholder maize producers in Malawi helped to increase maize production in 2006. The study added that the maize production in 2005/2006 was higher than in the 2001/2002 and 2002/2003 seasons, suggesting a large incremental impact of the input subsidy beyond the effect of better rainfall.

\section{ACKNOWLEDGEMENT}

The authors wish to express their gratitude to the Director-General of MPOB for permission to publish this article. The authors also wish to thank the staff of the Techno-Economics Research Unit of the Economics and Industry Development Division, $\mathrm{MPOB}$ for their kind assistance and support in conducting this research.

\section{REFERENCES}

Alwee, S S R S (2018). Is there a future in tissue culture for the oil palm industry? Paper presented at the International Seminar on Status of Oil Palm Tissue Culture Technology. Medan, Indonesia. 16 July 2018.

Alwee, S S R S; Roowi, S H; Teng, A K and Othman, A Z (2010). Progress of oil palm tissue culture in FELDA and its challenges. International Society for Oil Palm Breeder (ISOPB) Seminar on Advances in Oil Palm Tissue Culture. Yogyakarta, Indonesia. 29 May 2010.

Bloomberg, L P (2017). Beta. Bloomberg terminal, accessed on 8 March 2017.

Denning, G; Kabambe, P; Sanchez, P; Malik, A; Flor, R; Harawa, R; Nkhoma, P; Zamba, C; Banda, C; Magombo, C and Keating, M (2009). Input subsidies to improve smallholder maize productivity in Malawi: Toward an African green revolution. PLoS Biol., 7(1): e1000023. DOI:10.1371/journal. pbio. 1000023

Henson, I E and Dolmat, M T (2004). Seasonal variation in yield and developmental processes in an oil palm density trial on a peat soil: 1 . Yield and bunch number components. J. Oil Palm Res. Vol. 16(2): 88-105.

Hutabarat, S; Slingerland, M; Rietberg, P and Dries, L (2018). Costs and benefits of certification of independent oil palm smallholders in Indonesia.
International Food and Agribusiness Management Review, 21(6): 681-700.

ISOPB (1985). Newsletter Vol. 2(3), September 1985. The International Society for Oil Palm Breeders (ISOPB).

Janssen, K; Saatkamp, H and Komen, H (2018). Costbenefit analysis of aquaculture breeding programs. Genetics Selection Evolution, 50(2). DOI:10.1186/ s12711-018-0372-3.

Khaw, C and Ng, S (1997). Performance of commercial scale clonal oil palm (Elaeis guineensis Jacq.) plantings in Malaysia. Acta Hortic., 461: 251258. DOI: 10.17660/ ActaHortic.1998.461.27.

Kushairi, A; Tarmizi, A H; Zamzuri, I; OngAbdullah, M; Samsul, K R; Ooi, S E and Rajanaidu, N (2010). Production, performance and advances in oil palm tissue culture. International Society for Oil Palm Breeder (ISOPB) Seminar on Advances in Oil Palm Tissue Culture. Yogyakarta, Indonesia. 29 May 2010.

Kushairi, A; Loh, S K; Azman, I; Elina, H; OngAbdullah, M; Izuddin, Z B; Razmah, G; Sundram, $S$ and Parveez, G K A (2018). Oil palm economic performance in Malaysia and R\&D progress in 2017. J. Oil Palm Res. Vol. 30(2): 163-195.

Kushairi, A; Martienssen, R A and Sambanthamurthi, R (2018). A holistic view of current progress in oil palm tissue culture. International Seminar on Status of Oil Palm Tissue Culture Technology. Medan, Indonesia. 16 July 2018.

Low, E T L; Alias, H; Boon, S H; Shariff, E M; Tan, C Y A; Ooi, L C; Cheah, S C; Raha, A R; Wan, K L and Singh, R (2008). Oil palm (Elaeis guineensis Jacq.) tissue culture ESTs: Identifying genes associated with callogenesis and embryogenesis. BMC Plant Biology, 8(1): 62.

MPOB (2018a). Malaysian Oil Palm Statistics 2017. $37^{\text {th }}$ edition. MPOB, Bangi. p. 3.

MPOB (2018b). Oil Palm Replanting: Little Steps to A Giant Leap. MPOB, Bangi. 190 pp.

Mishra, P K and Rai, S C (2014). A cost-benefit analysis of indigenous soil and water conservation measures in Sikkim Himalaya, India. Mountain Research and Development, 34(1): 27-35.

Mutert, E and Fairhurst, T (1999). Oil palm clones: Productivity enhancement for the future. Better Crops International, 13(1): 45-47. 
Nair, K P (2010). The Agronomy and Economy of Important Tree Crops of the Developing World. First edition. Elsevier, New Delhi, India. 368 pp.

Ong-Abdullah, M; Tarmizi, A H; Zamzuri, I; Samsul K R; Ooi, S E; Naqiuddin, M H; Dalilah, A B; Norashikin, S; Nuraziyan, A; Pang, J T Y; Siti, R A R; Mohd, I Z A; Singh, R; Low, E T L; Nookiah, R; Ordway, J M; Jiang, N; Smith, S W; Lakey, N; Mohamad, A M; Ahmad, P G Kushairi, A; Martienssen, R A and Sambanthamurthi, R (2018). A holistic view of current progress in oil palm tissue culture. International Seminar on Status of Oil Palm Tissue Culture Technology. Medan, Indonesia. 16 July 2018.

Ong-Abdullah, M; Ordway, J M; Jiang, N; Ooi, S E; Kok, S Y; Sarpan, N; Azimi, N; Hashim, A T; Ishak, Z; Rosli, S K and Malike, F A (2015). Loss of Karma transposon methylation underlies the mantled somaclonal variant of oil palm. Nature, 525(7570): 533.

Ong-Abdullah, M; Ordway, J M; Jiang, N; Ooi, S E; Sarpan, N; Azimi, N; Hashim, A T; Ishak, Z; Rosli, S K; Nookiah, R; Singh, R; Low, E T L; Sachedeva, M; Smith, S W; Lakey, N; Martienssen, R A and Sambanthamurthi, R (2006). Tissue culture and epigenetics. The Planter, 92 (1087): 741-749.

Ooi, L H (2005). How much to pay for clonal oil palm? The Planter, 81(954): 547-566.

Penot, E and Ruf, F (2001). Rubber smallholders' flexibility No windfall, no crisis. People, Commodities and Natural Resources in Indonesia, 1996-2000. Curzon Press. p. 1-25.

Rajanaidu, N; Ainul, M M; Kushairi, A and Mohd Din, A (2013). Historical review of oil palm breeding for the past 50 years - Malaysian journey. Proc. of the International Seminar on Oil Palm Breeding - Yesterday, Today and Tomorrow. Kuala Lumpur. p. 11-28.

Soh, A C (2010). Review of strategies in breeding for oil palm clonal propagation. International Society for Oil Palm Breeder (ISOPB) Seminar on Advances in Oil Palm Tissue Culture. Yogyakarta, Indonesia. 29 May 2010.
Soh, A C; Mayes, S and Roberts, J A (2017). Oil Palm Breeding: Genetics and Genomics. First edition. CRC Press. Florida, USA. 464 pp.

Soh, A C (2018). Quo vadis (wither) oil palm tissue culture clonal propagation. International Seminar on Status of Oil Palm Tissue Culture Technology. Medan, Indonesia. 16 July 2018.

Sundram, K; Basiron, Y and Kheong, Y F (2010). Palm oil: A success story in green technology innovations. Paper presented at the International Greentech and Eco Products Exhibition and Conference Malaysia. Kuala Lumpur. 14-17 October 2010.

Tarmizi, A H; Zamzuri, I; Samsul, K R; OngAbdullah, M; Ooi, S E; Naqiuddin, M H and Dalilah, A B (2018). Oil palm (Elaeis guineensis Jacq.) somatic embryogenesis. Forestry Sciences, 85: 209-229.

The World Bank (2017). Inflation, consumer prices (annual \%). https://data.worldbank.org/ indicator/FP.CPI.TOTL.ZG, accessed on 10 March 2017.

UNCTAD (2016). Development and globalization: Facts and figures 2016. https://stats.unctad.org/ Dgff2016/annexes/ populationnote.html, accessed on 15 March 2017.

USDA (2012). Malaysia: Stagnating palm oil yields impede growth. United States Department of Agriculture (USDA), Foreign Agricultural Service. 5 pp.

Wahid, M B and Simeh, M A (2009). Issues related to production costs of palm oil in Malaysia. Oil Palm Industry Economic J. Vol. 9(2): 1-12.

Zamzuri, I; Arif, S M; Rajanaidu, S and Rohani, O (1998). Clonal oil palm planting material production: An economic analysis. The Planter, 74 (827): 597-619.

Zulkifli, H; Halimah, M; Chan, K W; Choo, Y M and Basri, W M (2010). Life cycle assessment for oil palm fresh fruit bunch production from continued land use for oil palm planted on mineral soil (Part 2). J. Oil Palm Res. Vol. 22: 887894. 